\title{
Legume Lectins: Proteins with Diverse Applications
}

\author{
Irlanda Lagarda-Diaz ${ }^{1}$, Ana Maria Guzman-Partida ${ }^{2}$ and Luz Vazquez-Moreno ${ }^{2, *}$ \\ CONACyT-Universidad de Sonora, Blvd. Luis Encinas y Rosales, Hermosillo, Sonora 83000, Mexico; \\ Irlanda.lagarda@unison.mx \\ 2 Coordinacion de Ciencia de los Alimentos, Centro de Investigacion en Alimentacion y Desarrollo, A.C., \\ Apartado Postal 1735, Hermosillo, Sonora 83304, Mexico; gupa@ciad.mx \\ * Correspondence: lvazquez@ciad.mx; Tel./Fax: +52-662-280-0058
}

Academic Editor: Els Van Damme

Received: 29 April 2017; Accepted: 5 June 2017; Published: 12 June 2017

\begin{abstract}
Lectins are a diverse class of proteins distributed extensively in nature. Among these proteins; legume lectins display a variety of interesting features including antimicrobial; insecticidal and antitumor activities. Because lectins recognize and bind to specific glycoconjugates present on the surface of cells and intracellular structures; they can serve as potential target molecules for developing practical applications in the fields of food; agriculture; health and pharmaceutical research. This review presents the current knowledge of the main structural characteristics of legume lectins and the relationship of structure to the exhibited specificities; provides an overview of their particular antimicrobial; insecticidal and antitumor biological activities and describes possible applications based on the pattern of recognized glyco-targets.
\end{abstract}

Keywords: lectin; legume; insecticidal; antimicrobial; cancer

\section{Introduction}

Currently, lectins are defined as carbohydrate binding proteins of non-immune origin that can recognize and bind simple or complex carbohydrates in a reversible and highly specific manner. For a long time, these proteins were named hemagglutinins, due to their ability to agglutinate red blood cells. At present, this concept is used when the specificity is unknown. It is also known that monomeric lectins do not exhibit this agglutinating activity [1]. Lectins are ubiquitously present in fungi, animals, bacteria, viruses and plants. Among plant lectins, those of legumes have been the most widely considered [2]. These lectins are abundant in the seeds and belong to a group of highly homologous proteins. However, their carbohydrate specificities and quaternary structures vary extensively [3], which greatly influences the type of recognized targets.

Throughout the history of lectin research, legume seeds have been screened for lectin activity. The existence of binding sites for specific carbohydrates, the main characteristic of lectins, is undoubtedly an important factor for determining their activity and future applications based on their properties. This review centers on the lectins of legumes, highlighting their specificity, particularities, main reported activities and potential applications.

\section{Structure of Legume Lectins}

Legume lectins represent the largest family of carbohydrate binding proteins, and their physicochemical and biological properties have been broadly studied [4-8]. Research of the plant lectin family using newer biochemical and biophysical strategies has significantly moved the field forward, and provided a model framework for studying protein-carbohydrate interactions. Although plant lectins share high sequence homology and exhibit comparable physicochemical and structural properties, the diversity of their carbohydrate recognition specificity is remarkable. Generally, 
the three-dimensional structure of plant lectins is characterized by $\beta$-sheets that are connected by $\alpha$ turns, $\beta$ turns and bends. In addition to short loops, the quaternary interfaces are formed between $\beta$-sheets. The $\beta$-sheets are connected by loops forming antiparallel chains usually devoid of $\alpha$ helices (Figure 1) [4,5,9-12].

(A)

(B)

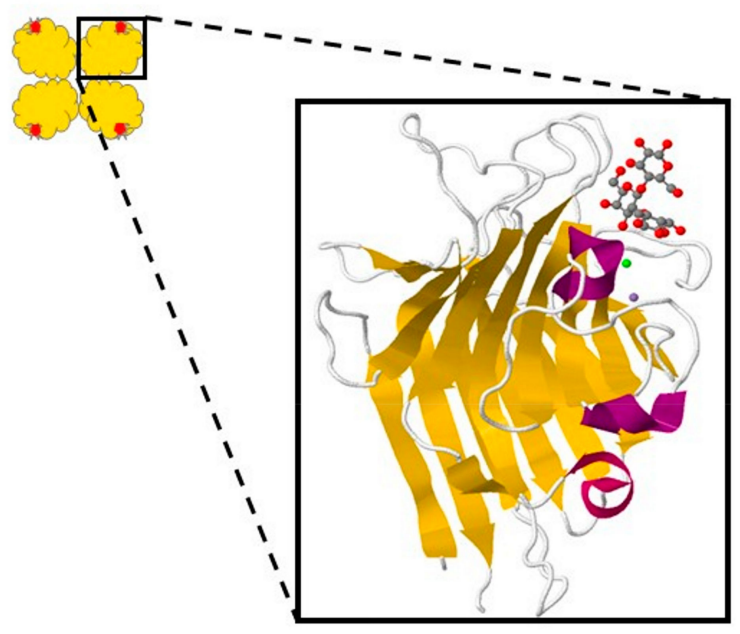

Figure 1. Overall structure of legume lectins. (A) tetramer with carbohydrate recognition domains (red); (B) amplified image of monomer with $\beta$-sheets (yellow), $\alpha$-turns (purple), metal binding sites (area with green and gray spheres) and carbohydrate recognition domain (area occupied by the grey and red molecule). Image modified from Protein Data Bank (accession code 1GZ9).

Analysis of legume lectin monomers reveals high similarity in sequence as well as structure, with only minor variations in the length of loops and strands. The monomer structures display a jellyroll motif best described as a sandwich of 25-30 kDa containing a carbohydrate recognition domain (CRD) and metal binding sites for divalent cations $\left(\mathrm{Ca}^{2+}\right.$ and $\left.\mathrm{Mn}^{2+}\right)$. However, in spite of strong similarities in primary, secondary and tertiary structures, the quaternary structures show considerable variations that lead to changes in the monomer-monomer interactions and the presence/absence of protein modifications, such as glycosylation. The impact of these variations has functional implications as they dictate the specificity of multivalent glycan binding [1,5,11,13-18]. Most legume lectins appear to assemble as homodimers or homo-tetramers (dimers of dimers), the stability of which is attributed to hydrophobic cooperation, hydrogen bonds and salt links [4,9,19].

Legume lectins are subdivided into two categories, those with indistinguishable or almost indistinguishable subunits, and those with a variety of subunits [20]. Phaseolus vulgaris lectins (PHA) are well-studied lectins of the first group [21-26]. There are more than forty structures of legume lectins reported in either the apo (ligand-free) or holo (sugar-bound) form in the Protein Data Bank [15,26-32]. However, data about lectins from wild legumes is rare.

Mexico has roughly 1800 species of wild legumes confined to various regions, and more than 33 percent are within the Sonoran Desert [5,33-42]. The isolation and purification of lectins from seeds of native plants such as Parkinsonia aculeata, Olneya tesota, Acacia constricta, Prosopis juliflora, Cercidium praecox, Caesalpinia caladenia and Phaseolus acutifolius has been described. Lectins from these plants have monomers of either 30 or $66 \mathrm{kDa}$ that also can form tetramers or dimers. In addition, it has been shown that these lectins involve a group of different isolectins, compared to those found in lectins of the Phaseolus genus [43-47].

On the other hand, the primary sequences of plant lectins have been used to infer evolutionary relationships, to reflect processing routes, to suggest folding patterns as well as to provide clues on how carbohydrate ligands fit into their binding pockets [20]. Direct amino acid sequencing has revealed 
homology among the lectins from the wild desert legumes A. constricta [6] and O. tesota [5,48], and more domesticated species like $P$. vulgaris and $P$. coccineus $[49,50]$. Furthermore, antibodies raised against PHA show reactivity with lectins from A. constricta, C. praecox and C. caladenia [6]. From these studies, it is clear that lectins have been conserved during the evolution of legumes and that the extensive homologies reflect taxonomical relationships among these plants [51].

\section{Specificity of Legume Lectins}

Legume lectins represent a crucial point in the study of the molecular basis of protein-carbohydrate interactions. Each has a CRD with a basic architecture accessible to both monosaccharides and/or oligosaccharides that confers remarkable divergence in their specificities [12,52]. Lectins can non-covalently interact with carbohydrates in a manner that is usually reversible and highly specific. Recognition can occur in the terminal or intermediate position of the glycan structure [53]. In all legume lectins, four invariant amino acid residues participate in the binding of the carbohydrate, yet each lectin shows different specificity $[18,54,55]$. The CRD pocket is formed by four loops adjacent to each other, but the loops are not close in sequence. These regions exhibit the highest residue variability and appear to be involved in specificity determination [56,57]. The CRD of legume lectins lies in close proximity to the metal binding sites, which may aid in binding activity [18], but are not often directly involved in carbohydrate binding [18].

Most lectins bind to mono- and oligosaccharides; however, more recently discovered lectins show specificity for complex sugars and glycoproteins. Generally, lectins show specificity for di-, tri- and tetra-saccharides with association constants significantly higher than those for the corresponding monosaccharides $[5,18,58]$. Some lectins have shown affinity towards carbohydrate structures not present in plants, such as the Thomsen-nouveau antigen or complex $\mathrm{N}$-glycan structures with terminal galactose and sialic acid residues [30]. The specificity of legume lectins for some typical animal glycans, has led to the suggestion that legume lectins play a role in plant defense against insects and/or predator animals $[59,60]$.

The legume lectins that have been purified and characterized as members of the complex type include, Griffonia simplicifolia IV lectin (GS IV) [5,61], Maackia amurensis lectin (MAH and MAL-1) [62], Cicer arietinum lectin [63], Saraca indica lectin [58,64] and P. vulgaris E and L lectins (PHA-E and PHA-L) $[5,23,26,65-69]$. Wild legume lectins from the Sonoran Desert also have shown varying degrees of specificity for some complex carbohydrates of glycoproteins. The hemagglutinating activity of $A$. constricta isolectins (VLs) and the P. juliflora lectin is strongly inhibited in the presence of asialofetuin and to a lesser extent with fetuin and thyroglobulin [6,40]. C. praecox and C. caladenia lectins are inhibited by fetuin and mucine [37]. O. tesota PF1 and PF3 lectins are inhibited by free monosaccharides and/or by complex carbohydrates of fetuin, thyroglobulin, immunoglobulin, mucine and ovalbumin, whereas PF2 is only inhibited by the intact glycoprotein [5]. Although glycan structures present in glycoproteins are known to have $\mathrm{N}$ and $\mathrm{O}$ linked oligosaccharides, desialylation of the glycan can result in an increase or decrease in lectin binding affinity [70]. The galactose residues found in glycosylated proteins are often capped with sialic acid, a characteristic that may alter the interaction with lectins, as is seen for Amaranthus caudatus and Abrus pulchellus [71,72].

Many studies on lectin-carbohydrate specificity have been published. Unfortunately, often specificity analyses are used to "specifically" determine structural motifs in glycoconjugates without taking into account the rather complex data on this subject. Furthermore, the choice of ligands used to assay lectin binding in some studies is limited either by natural or commercially available sources of glycans, or to simple mono- or disaccharides. Therefore, a critical re-evaluation of lectin binding specificities is required. Such studies using microarray techniques with immobilized glycans or immobilized lectins, dot blot assays to screen different lectins and antibodies with multiple oligosaccharides, combined with information gleaned using recombinant glycosyltransferases, are opening up new possibilities of generating a broader range of standard (neo)glycoconjugates with clearly defined structures [73]. 


\section{Antimicrobial Activity}

Antimicrobials have been used to treat diseases caused by bacteria and fungi and such treatments have significantly reduced the mortality rate from these infections in humans and animals. However, the extensive use of antimicrobial substances in medical, agricultural, and veterinary practices is a topic of great concern to clinical microbiologists all over the world due to the growing emergence of opportunistic microorganism strains resistant to drugs that cause serious infections [74-77]. Microbial resistance is a genetic phenomenon resulting in a reduction in effectiveness of drug therapy; it may be caused by mutations during the reproductive process of the microorganisms or by imported genes acquired through transduction, conjugation, and transformation mechanisms [78]. Therefore, there is a growing interest in developing new strategies for inhibiting the growth or survival of microorganisms based on the screening of new sources of natural compounds as alternatives to commercially available drugs [74,79].

A large number of proteins with antibacterial, antifungal and/or antiviral activity have been isolated from the seeds, tubers, and rhizomes of different plants, where they accumulate to high levels and may function as a reserve source of amino acids and metal ions [80]. These proteins may directly interfere with the growth, multiplication and spread of microbial agents by different mechanisms [81], as in the case of lectins, by agglutination and/or microorganism immobilization. Plant lectins often are present at potential sites of microbial invasion and their binding to fungal structures led to the inhibition of fungal growth and germination. Studies carried out with soy bean and common lentil agglutinins provide evidence for these roles [51,82-84]. A main characteristic of lectins is their ability to interact with glyco-components present on the cell membrane surface, in cytoplasmic and nuclear structures and in the extracellular matrix of cells and tissues from almost all kingdoms of life [85]. Therefore, plant lectins are thought to play important roles in the plant immune defense and emerge as potential antimicrobial candidates for drug therapies. The antimicrobial effect of legume lectins is shown in Table 1. Although many lectins show antimicrobial activity, clinical trials are needed to establish therapeutic efficacy, to optimize dosage, delivery and bioavailability, and to assess potential allergic reactions [86].

\subsection{Bacteria}

The antibacterial activity of lectins results from their interaction with a wide variety of complex carbohydrates of the bacterial cell wall, such as teichoic and teichuronic acids, peptidoglycans and lipopolysaccharides [2,85]. Lectins of Triticum vulgare, Dolichos lablab L., Trigonella foenumgraecum, Trifolium alexandrium L., Bauhinia variegata L. and Delonix regia have shown antimicrobial activity against Mycobacterium rhodochrous, Bacillus cereus, B. megaterium, B. sphaericus, Escherichia coli, Serratia marcescens, Corynebacterium xerosis and Staphylococcus aureus [86] Lectins from the Vicieae tribe strongly react with the bacterial cell wall components, muramic acid, $\mathrm{N}$-acetylmuramic acid and muramyl dipeptides [87]. Nevertheless, although legume seed lectins can recognize and bind to the constituents of the bacterial cell wall, such binding does not imply that these interactions occur in vivo, and certainly does not prove that these lectins are involved in the protection of seedlings against bacteria [51].

It is thought that plant lectins do not alter the membrane structure and/or permeability nor disturb the normal intracellular processes of invading microbes, since they exert an indirect effect that is based on interactions with cell wall carbohydrates or extracellular glycans [60]. However, electron microscopy studies revealed that treatment with Araucaria angustifolia lectin promoted morphologic alterations, including the presence of pores in the membrane of Gram-positive bacteria, and bubbling on the cell wall of Gram-negative bacteria [88]. Others reported that the antibacterial activity of lectins occurred through the interactions of the lectins with $\mathrm{N}$-acetylglucosamine, $\mathrm{N}$-acetylmuramic acid and tetrapeptides linked to $\mathrm{N}$-acetylmuramic acid present in the cell wall of Gram-positive bacteria, or to lipopolysaccharides present in the cell wall of Gram-negative bacteria [87]. 
Table 1. Antimicrobial effect of legume lectins.

\begin{tabular}{|c|c|c|c|c|}
\hline Lectin & Carbohydrate/Glycoprotein Receptor & $\begin{array}{c}\text { Type of } \\
\text { Microorganism }\end{array}$ & Mechanism of Action & Reference \\
\hline $\begin{array}{c}\text { From Leguminosae, } \\
\text { tribe: Vicieae } \\
\text { Diocleae } \\
\text { Phaseoleae } \\
\text { Erithrinea } \\
\text { Glycineae } \\
\text { Sophoreae } \\
\text { Galegeae } \\
\text { Genisteae } \\
\text { Loteae } \\
\text { Acacieae }\end{array}$ & $\begin{array}{c}\text { Components of the cell Wall: Muramic acid, } \\
N \text {-acetylmuramic acid, } \\
N \text {-acetylglucosamine, Muramyl-dipeptides, } \\
\text { glucosaminyl-muyamyl-dipeptide, } \\
\text { lipopolysacharides }\end{array}$ & Bacteria & $\begin{array}{c}\text { Form a channel or pore on cell } \\
\text { membrane and the cell dies as a result of } \\
\text { the out flowing of cellular contents. } \\
\text { Bacterial aggregation and inhibition } \\
\text { bacterial cell division }\end{array}$ & {$[79,83,87,89-91]$} \\
\hline $\begin{array}{l}\text { Astragalus } \\
\text { mongholicus } \\
\text { agglutinin } \\
\text { P. vulgaris agglutinin } \\
\text { P. coccineus } \\
\text { agglutinin } \\
\text { Soy bean agglutinin } \\
\text { Peanut agglutinin }\end{array}$ & $\begin{array}{l}\text { Components of fungal cell wall: Chitin, } \\
\text { sialic acid }\end{array}$ & Fungi & $\begin{array}{l}\text { Binding to hyphae, swollen hyphal, } \\
\text { vacuolization of the cell content, and } \\
\text { enhanced susceptibility to cell wall lysis } \\
\text { of the hyphal induced by osmotic shock, } \\
\text { producing more susceptibility to other } \\
\text { stress conditions. This condition } \\
\text { produces poor absorption of nutrients, } \\
\text { interference spore germination and } \\
\text { rupture of the cell wall. }\end{array}$ & {$[79,83,91-98]$} \\
\hline $\begin{array}{l}\text { Concanavalin A } \\
\text { Psophocarpus } \\
\text { tetragonolubus } \\
\text { agglutinin } \\
\text { Lens culinaris } \\
\text { agglutinin } \\
\text { Vicia faba agglutinin } \\
\text { Pisum sativum } \\
\text { agglutinin } \\
\text { Erythroagglutinin }\end{array}$ & $\begin{array}{l}\text { Components of viral envelope: } \\
\text { Glycoproteins Gp120/Gp41, sialic acid }\end{array}$ & Virus & $\begin{array}{l}\text { Bind to the glycosylated envelope } \\
\text { protein and block cellular entry (interfere } \\
\text { with replication cycle) }\end{array}$ & [98-105] \\
\hline
\end{tabular}

In addition to these findings, lectins from the legumes from Canavalia ensiformis, T. foenumgraecum, Arachis hypogaea, Cajanus cajan, P. vulgaris and Pisum sativum were shown to inhibit biofilm formation by Streptococcus mutans, but the growth of planktonic cells was not affected [89]. Since bacterial biofilms make disinfection procedures more difficult by increasing bacterial resistance to detergents and antibiotics, the inhibition of biofilm formation and development by legume lectins could be a useful characteristic of these proteins. Furthermore, the rapid evolution of bacteria with antibiotic resistance (in particular, multidrug resistant bacteria or superbugs) has reduced the efficacy of conventional treatments against their biofilms. Hence, development of non-antibiotic alternatives that could efficiently treat or reduce biofilms should become a priority. Furthermore, research focused on finding lectins that reduce superbugs could represent an interesting alternative drug therapy that deserves further attention.

\subsection{Fungi and Yeasts}

Regardless of the considerable number of lectins that have been characterized, only a small number have shown antifungal effects. Because plant lectins do not penetrate the cell wall or the membrane to reach the cytoplasm of fungi, direct inhibition of fungal growth by lectins is unlikely. In spite of this, indirect responses produced by the attachment of lectins to chitin and other glycans on the fungal surface could affect fungal survival or other activities [105,106].

Lectin binding to hyphae could result in inhibition of fungi growth as a result of poor nutrient absorption as well as by interference with the spore germination process [107]. Lectins can cause different morphological changes that render fungi more vulnerable to differing stress conditions [108]. For example, in one study, lectin interactions resulted in swollen hyphae, vacuolization of the cell content and improved lysis of hyphal cell wall, that, in turn, increased susceptibility of fungi to osmotic shock [107]. In another case, it was suggested that small antifungal lectins could penetrate the fungal cell wall and reach the cell membrane where blocking of active sites of enzymes could alter cell wall morphogenesis $[108,109]$.

Some reports indicate that lectins from the legumes Astragalus mongholicus, P. coccineus, Archidendron jiringa Nielsen, B. ungulata, Glycine max, Indigofera heterantha and A. hypogaea can exhibit antifungal activity against various species of phytopathogenic fungi, such as Botrytis cinerea, Fusarium oxysporum, 
F. moniliforme, F. solani, Colletorichum sp., Drechslera turcia, and Exserohilum turcicum, as well as pathogenic fungi such as Candida albicans, Penicillium italicummm, and Aspergillus sp. [82,91-93,110,111]. Additional studies are required to elucidate the molecular basis for the antifungal activity of individual lectins as the ability of lectins to inhibit growth differs among fungal species.

\subsection{Virus}

Plant lectins with antiviral activity are of substantial therapeutic interest. Some of these carbohydrate binding proteins exhibit significant activity against human immunodeficiency virus (HIV) and other viruses [97]. Retroviruses, such as HIV, have a surface covered by highly glycosylated virally-encoded glycoproteins, e.g., gp120 (that contains high mannose and/or hybrid glycans) and gp41. The carbohydrates on these proteins are particularly important because the glycans can be used as tools to render the virus easily recognized by the immune system, and thus susceptible to immunological neutralization [112]. The interactions between host and proteins from the viral envelop also can be altered by compounds that specifically recognize and bind glycans. Furthermore, lectins can crosslink surface viral glycans and thereby prevent interactions with other co-receptors [83].

Antiviral lectins used as therapeutic agents offer lower toxicity and can be included in topical applications. Generally, lectins are odorless, and resistant to high temperatures and low $\mathrm{pH}$, ideal properties for development of microbicide drugs [86].

Most current antiviral therapeutics prevent the viral life cycle, or inhibit the entrance of the virus into host cells [113]. The antiviral action of plant lectins varies extensively depending upon their carbohydrate specificity. Corona virus are highly susceptible to mannose specific lectins that interfere with the viral attachment in early phases of the replication cycle and suppress viral development by binding towards the end of the viral infection cycle [114]. Other antiviral non-legume lectins with encouraging properties include griffithsin (GRFT), cyanovirin (CV-N) and banana lectin (BanLec), and BanLec has been recommended as an antiviral microbicide. Most often antiviral lectins are recommended for incorporation into vaginal and rectal gels, creams or suppositories that act as a barrier to prevent HIV transmission. In such processes, lectins bind the virus preventing its entry and fusion to target cells, consequently averting contamination [115].

Several legume lectins possess antiviral activity. Lectins like C. ensiformis agglutinin (Con A), Lens culinaris agglutinin (LCA), Vicia faba agglutinin, P. sativum agglutinin (PSA) and PHA-E bind to the envelope glycoprotein gp120 and to inhibit fusion of HIV-infected cells with CD4 cells by a carbohydrate-specific interaction with the HIV-infected cells [103]. In addition, G. max agglutinins inhibit HIV-1 reverse transcriptase activity [116]. Although glycan structures of viral proteins involve high mannose, further research in this area is needed to explore lectins that recognize structures with different sugars such as sialic acid, fucose and $N$-acetyl glucosamine with the aim of developing novel approaches and therapies in the field of virus biology.

\section{Insecticidal Activity}

Legume lectins are toxic to a broad spectrum of insects representing several orders including, Coleoptera, Diptera, Lepidoptera, Hymenoptera, Isoptera, Neuroptera and Homoptera. In this regard, the family of leguminous lectins is the most studied due to its insecticidal potential. A great number of legume lectins have shown insecticidal activity including those from C. ensiformis, P. sativum, P. vulgaris, Glechoma hederacea, G. simplicifolia, O. tesota (PF2) and B. monandra $[8,117,118]$.

These lectins showed harmful effects in the different developmental stages of insects (larvae and adults). In this regard, they may increase mortality, delay development and/or adult emergence and reduce fecundity. Usually, the effect of lectins on insects is evaluated by feeding larvae with artificial seeds containing the lectin or with transgenic plants that overexpress the lectin of interest. The expression of a given lectin in transgenic plants is only possible if the lectin molecular sequence is well characterized and also requires an available transformation protocol for the desired plant species [119]. 
In the last twenty years, research has focused on elucidating the mode of action of insecticidal lectins. In general, lectins can exert a toxic effect via binding to the peritrophic membrane (PM), peritrophic gel (PG) or the brush-border microvilli of epithelial cells (Figure 2) [120]. The PM or PG is a film surrounding the food bolus in most insects and is composed of chitin and proteins. Some non-legume lectins with insecticidal activity such as the Rhizoctonia solani agglutinin and Sambucus nigra agglutinin II can pass through the PM of the red flour beetle, Tribolium castaneum. This ability to reach the endoperitrophic space is governed by the dimensions of the molecule and the charge and size of the PM pores [121].

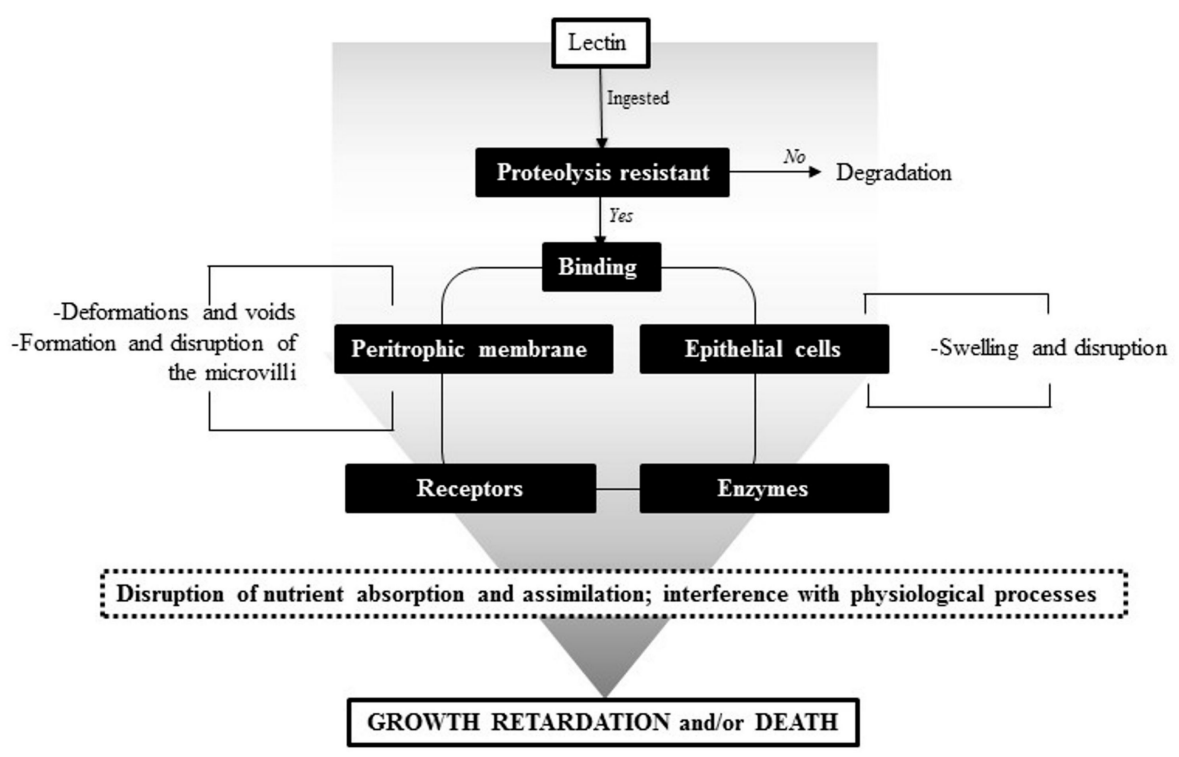

Figure 2. Insecticidal action mechanism for lectins.

In the case of insects lacking a PM, the insecticidal effect of lectins may be exerted by their direct interaction with glycoconjugates present on the cell epithelium [122]. In fact, the insecticidal activity of lectins relies on their binding properties to sugars present on the surface of the insect gut epithelial cells. In insects, the surface of epithelial cells is rich in glycoproteins that, in addition to their determinant roles for the proper gut function, provide a number of available targets for lectin binding.

The interaction of lectins with different glycoproteins or glycan structures in insects may interfere with important physiological processes (Table 2). Although the key receptors for lectins could be localized on the surface of gut epithelial cells, if lectins are internalized, they may interact with a new set of targets located in the intracellular space, allowing the lectin to interfere with particular metabolic pathways. Such internalization has been more studied for non-legume lectins. For example, the garlic leaf lectin, which affects survival and development of the moth Helicoverpa armigera, was found to be internalized by binding to a glycosylated alkaline phosphatase anchored to the insect midgut membrane. In addition, Galantus nivalis lectin was reported to cross the midgut epithelium of Nilaparvata lugens and co-localize in the fat body and hemolymph. Such co-localization was proposed to occur via a carrier-receptor, ferritin. The internalization of the Colocasia esculenta tuber agglutinin into insect hemolymph also was demonstrated, suggesting it could interact with various $N$-glycosylated intracellular targets, which may, in part, explain the lectin toxicity [122]. Although the complete mechanism by which some lectins are able to cross midgut epithelial cells is not yet fully understood, available evidence has highlighted the implication of clathrin-mediated endocytosis as part of this process [123,124].

Regardless of the mechanisms involved in lectin interactions with insect cells, in order to be toxic, a lectin must avoid degradation by the digestive enzymes from the insect gut. The insecticidal effect 
of some lectins is attributed to the resistance of these proteins to proteolysis and to their properties of stability in a wide $\mathrm{pH}$ range. For example, PF2, an insecticidal lectin to Zabrotes subfasciatus, is resistant to in vitro proteolysis by insect digestive enzymes. This is in contrast to PHA-E lectin that is digested after $4 \mathrm{~h}$ of incubation with these enzymes, and therefore is not toxic for this insect [8]. Other lectins with insecticidal activity that share the common feature of resistance to proteolysis by different digestive enzymes include, G. simplicifolia II lectin (GS II), Ulex europeus agglutinin (UEA) and B. monandra lectin $[117,118]$. The degree of resistance to digestive enzymes depends on the capacity of the lectin to bind to glycoconjugates of the insect gut. GS II mutant lectins lacking the ability to bind carbohydrates displayed sensitivity to proteolysis by digestive enzymes with a consequent loss of toxicity [125].

Table 2. Receptors of plant lectins of different insects.

\begin{tabular}{|c|c|c|c|}
\hline Lectin & Receptor & Insect & Reference \\
\hline $\begin{array}{l}\text { Allium sativum L. bulbs } \\
\text { (ASAI and ASAII) }\end{array}$ & Aminopeptidase N Sucrase & Acyrthosiphon pisum & {$[126]$} \\
\hline Galantus nivalis lectin & Ferritin & $\begin{array}{l}\text { Nilaparvata lunges } \\
\text { Spodoptera littoralis }\end{array}$ & $\begin{array}{l}{[127]} \\
{[128]}\end{array}$ \\
\hline $\begin{array}{l}\text { Myracrodruon urundeuva } \\
\text { leaf lectin (MuLL) }\end{array}$ & Trypsin $\alpha$-amylase & Aedes aegypti & [129] \\
\hline $\begin{array}{c}\text { Bauhinia monandra leaf } \\
\text { lectin (BmoLL) }\end{array}$ & $\alpha$-amylase & $\begin{array}{l}\text { Callosobruchus } \\
\text { maculatus }\end{array}$ & [117] \\
\hline Concanavalin A & $\begin{array}{l}\beta \text {-glucosidases } \\
\text { cathepsin L }\end{array}$ & Rhopalosiphum padi L. & [130] \\
\hline $\begin{array}{l}\text { Allium sativum Leaf } \\
\text { Agglutinin (ASAL) }\end{array}$ & $\begin{array}{l}\text { (Nicotinamide adenine } \\
\text { dinucleotide reduced) quinone } \\
\text { oxidoreductase }\end{array}$ & Brown planthopper & {$[131]$} \\
\hline \multirow[t]{2}{*}{$\begin{array}{l}\text { Colocasia esculenta tuber } \\
\text { agglutinin (CEA) }\end{array}$} & $\begin{array}{c}\text { Vacuolar ATP synthase } \\
\text { ATP synthase } \\
\text { Heat shock protein } 70 \text { clathrin } \\
\text { heavy chain }\end{array}$ & Lipaphis erysimi & [122] \\
\hline & $\begin{array}{l}\text { Sarcoplasmic endoplasmic } \\
\text { reticulum typ } \mathrm{Ca}^{2+} \text { ATPase }\end{array}$ & Bemisia tabaci & [122] \\
\hline PF2 lectin & $\begin{array}{c}\alpha \text {-amylase } \\
\text { V-type proton ATPase } \\
\text { Arginine kinase } \\
\text { Prohibitin } \\
\text { Polyubiquitin } \\
\text { Actin } \\
\text { ATP-dependent RNA helicase } \\
\text { ATP synthase subunit alpha } \\
\text { Mitochondrial-processing } \\
\text { peptidase } \\
\alpha \text {-tubulin } \\
\text { Odorant receptor } \\
\text { Cytochrome c oxidase }\end{array}$ & Zabrotes subfasciatus & {$[132]$} \\
\hline \multirow[t]{2}{*}{ Allium sativum lectin } & $\begin{array}{l}\text { Aminopeptidase } \\
\text { Cadherin-N } \\
\text { Polycalin } \\
\text { Alkaline phosphatase } \\
\text { Cytochrome P450 }\end{array}$ & $\begin{array}{l}\text { Helicoverpa } \\
\text { Armigera }\end{array}$ & [134] \\
\hline & $\begin{array}{c}\text { Alanyl } \\
\text { Aminopeptidase N } \\
\text { Sucrase }\end{array}$ & $\begin{array}{l}\text { Acyrthosiphon } \\
\text { Pisum }\end{array}$ & [134] \\
\hline
\end{tabular}

In summary, the insecticidal effect exhibited by several plant lectins is a complex phenomenon that relies on the capacity of the lectin to interfere with critical physiological processes during insect 
development. Such interference often may be mediated by a lack of nutrient absorption that occurs when midgut epithelial cells are atrophied as a result of the interaction of lectins with glyco-targets located either on the surface or inside the cell. Studies of the recognition of plant lectins by insect gut glyco-targets can allow one to develop hypotheses on which cellular pathways are affected by the insecticidal activity. These pathways vary depending on the type of insect and the lectin, and could be as diverse as the type of recognized glycan or receptors, and might include the effectors of energy metabolism, and redox and ionic homeostasis (summarized in Table 2).

Finally, the study of potential non-yet-identified insecticidal plant lectins may contribute to the development of distinctive tools for sustainable pest control. However, in this regard, care must be taken considering the effect lectins might exert on beneficial insects as well.

\section{Antitumor Activity}

Recently, an increased interest in the potential of plant lectins as cancer therapeutic agents has become evident. Lectins can be used to study the metastatic distribution patterns, the expression profiles of cancer cells glycoconjugates and their biological effects in various tumors. It is well known that carbohydrates present on the cell membrane are important for cell recognition, communication and adhesion. In cancer, these interactions are essential for tumor progression and metastasis. In tumor cells, glycosylation is generally altered in comparison with normal cells and these alterations can be detected by lectins $[135,136]$. Litynska et al. compared the lectin-binding pattern in different human melanoma cell lines using the PHA-L lectin and other non-legume lectins, including the Galanthus nivalis lectin, S. nigra lectin, MAL, Datura stramonium agglutinin and wheat germ agglutinin (WGA). Studies demonstrated that acquisition of metastatic potential of tumor cells is correlated with the expression of branched and sialylated complex $N$-oligosaccharides [137]. Interestingly, the binding of MAL-I to gastric cancer cells was proportional to their metastatic capacity, and a high expression of $\alpha(2,3)$-linked sialic acids was closely correlated with lymph node metastasis [137]. Korourian et al. used G. simplicifolia lectin-I (GS I) and Vicia vilosa agglutinin (VVA) to establish an expression analysis of carbohydrate antigens in human breast ductal carcinoma in situ (DCIS). Both lectins showed a significant association with nuclear grade (cell size and uniformity) of DCIS [138]. Positive correlations also were found between the expression of VVA- and GSI-reactive structures and tumor grade in DCIS patients, suggesting that the glycoconjugates found in these antigens are associated with invasiveness in DCIS [138]. PHA can be used to discriminate between hepatocellular carcinoma and benign liver disease [139]. This suggests that lectins could potentially be used to develop prognostic tools for cancer diagnosis and the detection of metastasis, and to some extent to estimate the severity of the clinical case.

In addition to these uses, plant lectins have shown in vivo and in vitro antitumor activity. Lectins with the potential to induce inhibition of tumor cell growth, such as, Con A, Mistletoe type-I lectins and PHA are currently in different phases of clinical trials [138,140]. Plant lectins can modify the expression of interleukins and some protein kinases and in this way modulate the immune system. Furthermore, in cancers, lectins could alter the signaling pathways involved in the expression of members of the Bcl-2, Autophagy (ATG) related, and caspase families, as well as p53, ERK, Ras-Raf, and BNIP3, and thereby induce both apoptosis and autophagy [141]. Soybean lectin produces reactive oxygen species in a dose-dependent manner in HeLa cells inducing apoptosis, autophagy and DNA damage in the cells [142].

The cell surface carbohydrates are key targets for lectins; in cancer, a general pathway involves recognition of carbohydrate receptors triggering the activation of enzymes such as MBL-associated serine proteases [143]. However, the binding of lectins to glycans on the cell membrane may not be sufficient to induce apoptosis. Kim et al. showed that cell death requires lectin endocytosis that triggers signaling for apoptosis [143]. Con A is cytotoxic to hepatoma cell lines. Its toxicity is mediated primarily by its binding to the mannose moiety of cell membrane glycoproteins, with subsequent internalization and accumulation in the mitochondria. Autophagy is then activated, leading to 
lysosomal degradation of the affected mitochondria and, ultimately, cell death [144,145]. Overall, these findings of cancer research have revealed the mechanisms responsible for the antitumor action of different plant lectins. These mechanisms are varied and depend upon different factors such as the tumor cell origin and type as well as lectin concentration.

\section{Conclusions}

The screening and characterization of novel lectins from legume resources has allowed the discovery of proteins with a great capacity to distinguish specific glycans from a diversity of glyco-targets found in a variety of organisms. Legume lectins could be potential candidates for developing tools based on protein-carbohydrate interactions with variable specificities. Lectin-mediated drugs focused on targeting specific cells could lead to promising anticancer and antimicrobial treatments, which would directly impact areas of economic importance, such as the pharmaceutical and food industries and agriculture. Additionally, the use of lectins against insect pests could provide a form of sustainable pest control.

More research is needed to explore and support the therapeutic effect of lectins. Studies of action mechanisms, the relationship between the role of the lectins and their molecular features, and finally, their effect in modulating the expression of proteins and genes are required to move forward the use of lectins for clinical applications.

Domesticated legumes provide an accessible and abundant source of lectins, unlike wild legumes, which, in some regions, may even be considered protected species. In some cases, successful recombinant production of lectins would be a key factor in whether a specific lectin could find use in a feasible industrial application. The overexpression of recombinant lectins remains a great challenge, even more so for those lectins where the lack of adequate post-translational modifications could compromise their activity.

Acknowledgments: The authors thank Joy Winzerling for her critical reading and editing of the manuscript.

Author Contributions: All authors compiled the information, wrote the review, read and approved the final manuscript.

Conflicts of Interest: The authors declare no conflict of interest.

\section{Abbreviations}

$\begin{array}{ll}\text { CRD } & \text { Carbohydrate recognition domain } \\ \text { PM } & \text { Peritrophic membrane } \\ \text { PG } & \text { Peritrophic gel } \\ \text { PHA } & \text { Phaseolous vulgaris agglutinin } \\ \text { MAL-1 } & \text { Maackia amurensis lectin 1 } \\ \text { DCIS } & \text { Human breast ductal carcinoma in situ } \\ \text { GS IV } & \text { Griffonia simplicifolia IV lectin } \\ \text { MAH and MAL-1 } & \text { Maackia amurensis lectins } \\ \text { VLs } & \text { Acacia constricta isolectins } \\ \text { WGA } & \text { Wheat germ agglutinin } \\ \text { LCA } & \text { Lens culinaris agglutinin } \\ \text { PSA } & \text { Pisum sativum agglutinin } \\ \text { GS II } & \text { Griffonia simplicifolia II lectin } \\ \text { UEA } & \text { Ulex europeus agglutinin } \\ \text { ASAI and ASAII } & \text { Allium sativum L. bulbs } \\ \text { MuLL } & \text { Myracrodruon urundeuva leaf lectin } \\ \text { BmoLL } & \text { Bauhinia monandra leaf lectin } \\ \text { ASAL } & \text { Allium sativum Leaf Agglutinin } \\ \text { CEA } & \text { Colocasia esculenta tuber agglutinin } \\ \text { GS I } & \text { Griffonia simplicifolia lectin-I } \\ \text { VVA } & \text { Vicia vilosa agglutinin }\end{array}$




\section{References}

1. Sharon, N.; Lis, H. History of lectins: From hemagglutinins to biological recognition molecules. Glycobiology 2004, 14, 53r-62r. [CrossRef] [PubMed]

2. Hamid, R.; Masood, A.; Wani, I.H.; Rafiq, S. Lectins: Proteins with diverse applications. J. Appl. Pharm. Sci. 2013, 3, S93-S103.

3. Loris, R.; Hamelryck, T.; Bouckaert, J.; Wyns, L. Legume lectin structure. BBA-Protein Struct. Mol. Enzymol. 1998, 1383, 9-36. [CrossRef]

4. Sharon, N.; Lis, H. Legume lectins a large family of homologous proteins. FASEB J. 1990, 4, 3198-3208. [PubMed]

5. Vázquez-Moreno, L.; Ortega-Nieblas, M.; Robles-Burgueño, M.R.; Ramos-Clamont, G. Purification of complex carbohydrate specific lectins from Olneya tesota seeds using tandem affinity chromatography. Int. J. Biochromatogr. 2000, 5, 83-90.

6. Guzman-Partida, A.M.; Robles-Burgueno, M.R.; Ortega-Nieblas, M.; Vazquez-Moreno, I. Purification and characterization of complex carbohydrate specific isolectins from wild legume seeds: Acacia constricta is (vinorama) highly homologous to Phaseolus Vulgaris lectins. Biochimie 2004, 86, 335-342. [CrossRef] [PubMed]

7. Nasi, A.; Picariello, G.; Ferranti, P. Proteomic approaches to study structure, functions and toxicity of legume seeds lectins. Perspectives for the assessment of food quality and safety. J. Proteom. 2009, 72, 527-538. [CrossRef] [PubMed]

8. Lagarda-Diaz, I.; Guzman-Partida, A.M.; Urbano-Hernandez, G.; Ortega-Neblas, M.M.; Robles-Burgueno, M.R.; Winzerling, J.; Vazquez-Moreno, L. Insecticidal action of PF2 lectin from Olneya tesota (palo fierro) against Zabrotes subfasciatus larvae and midgut glycoconjugate binding. J. Agric. Food Chem. 2009, 57, 689-694. [CrossRef] [PubMed]

9. Sharma, V.; Surolia, A. Analyses of carbohydrate recognition by legume lectins: Size of the combining site loops and their primary specificity. J. Mol. Biol. 1997, 267, 433-445. [CrossRef] [PubMed]

10. Hamelryck, T.W.; Loris, R.; Bouckaert, J.; Doa-Thi, M.H.; Strecker, G.; Imberty, A.; Fernandez, E.; Wyns, L.; Etzer, M.E. Carbohydrate binding, quaternary structure and a novel hydrophobic binding site in two legume lectin oligomers from Dolichos biflorus. J. Mol. Biol. 1999, 288, 1037. [CrossRef] [PubMed]

11. Vijayan, M.; Chandra, N. Lectins. Curr. Opin. Struct. Biol. 1999, 9, 707-714. [CrossRef]

12. Sharon, N.; Lis, H. How proteins bind carbohydrates: Lessons from legume lectins. J. Agric. Food Chem. 2002, 50, 6586-6591. [CrossRef] [PubMed]

13. Hamelryck, T.W.; Loris, R.; Bouckaert, J.; Wyns, L. Structural features of the legume lectins. Trends Glycosci. Glycotechnol. 1998, 10, 349-360. [CrossRef]

14. Bouckaert, J.; Hamelryck, T.; Wyns, L.; Loris, R. Novel structures of plant lectins and their complexes with carbohydrates. Curr. Opin. Struct. Biol. 1999, 9, 572-577. [CrossRef]

15. Buts, L.; Dao-Thi, M.H.; Loris, R.; Wyns, L.; Etzler, M.; Hamelryck, T. Weak protein-protein interactions in lectins: The crystal structure of a vegetative lectin from the legume Dolichos biflorus. J. Mol. Biol. 2001, 309, 193-201. [CrossRef] [PubMed]

16. Brinda, K.V.; Mitra, N.; Surolia, A.; Vishveshwara, S. Determinants of quaternary association in legume lectins. Protein Sci. 2004, 13, 1735-1749. [CrossRef] [PubMed]

17. Etzler, M.E.; Surolia, A.; Cummings, R.D. L-type lectins. In Essentials of Glycobiology, 2nd ed.; Varki, A., Cummings, R., Esko, J., Freeze, H., Stanley, P., Bertozzi, C., Hart, G., Etzler, M., Eds.; Cold Spring Harbor Laboratory Press: New York, NY, USA, 2009; Chapter 28, pp. 403-414.

18. Ambrosi, M.; Cameron, N.R.; Davis, B.G. Lectins: Tools for the molecular understanding of the glycocode. Org. Biomol. Chem. 2005, 3, 1593-1608. [CrossRef] [PubMed]

19. Manoj, N.; Suguna, K. Signature of quaternary structure in the sequences of legume lectins. Protein Eng. 2001, 14, 735-745. [CrossRef] [PubMed]

20. Rudiger, H.; Gabius, H.J. Plant lectins: Occurrence, biochemistry, functions and applications. Glycoconj. J. 2001, 18, 589-613. [CrossRef] [PubMed]

21. Felsted, R.L.; Leavitt, R.D.; Bachur, N.R. Purification of the phytohemagglutinin family of proteins from red kidney beans (Phaseolus vulgaris) by affinity chromatography. Biochim. Biophys. Acta 1975, 405, 72-81. [CrossRef] 
22. Felsted, R.L.; Li, J.; Pokrywka, G.; Egorin, M.J.; Spiegel, J.; Dale, R.M. Comparison of Phaseolus vulgaris cultivars on the basis of isolectin differences. Int. J. Biochem. 1981, 13, 549-557. [CrossRef]

23. Cummings, R.D.; Kornfeld, S. Characterization of the structural determinants required for the high affinity interaction of asparagine-linked oligosaccharides with immobilized Phaseolus vulgaris leukoagglutinating and erythroagglutinating lectins. J. Biol. Chem. 1982, 257, 11230-11234. [PubMed]

24. Fleischmann, G.; Mauder, I.; Illert, W.; Rudiger, H. A one-step procedure for isolation and resolution of the Phaseolus vulgaris isolectins by affinity-chromatography. Biol. Chem. Hoppe-Seyler 1985, 366, 1029-1032. [CrossRef] [PubMed]

25. Hamelryck, T.W.; DaoThi, M.H.; Poortmans, F.; Chrispeels, M.J.; Wyns, L.; Loris, R. The crystallographic structure of phytohemagglutinin-1. J. Biol. Chem. 1996, 271, 20479-20485. [CrossRef] [PubMed]

26. Nagae, M.; Soga, K.; Morita-Matsumoto, K.; Hanashima, S.; Ikeda, A.; Yamamoto, K.; Yamaguchi, Y. Phytohemagglutinin from Phaseolus vulgaris (PHA-E) displays a novel glycan recognition mode using a common legume lectin fold. Glycobiology 2014, 24, 368-378. [CrossRef] [PubMed]

27. Pérez, S.; Sarkar, A.; Rivet, A.; Breton, C.; Imberty, A. Glyco3d: A portal for structural glycosciences. Glycoinformatics 2015, 1273, 241-258.

28. Bouckaert, J.; Loris, R.; Poortmans, F.; Wyns, L. Crystallographic structure of metal-free concanavalin a at 2.5 angstrom resolution. Proteins 1995, 23, 510-524. [CrossRef] [PubMed]

29. Loris, R.; Casset, F.; Bouckaert, J.; Pletinckx, J.; Daothi, M.H.; Poortmans, F.; Imberty, A.; Perez, S.; Wyns, L. The monosaccharide binding-site of lentil lectin: An X-ray and molecular modeling study. Glycoconj. J. 1994, 11, 507-517. [CrossRef] [PubMed]

30. Ruzheinikov, S.N.; Mikhailova, I.Y.; Tsygannik, I.N.; Pangborn, W.; Duax, W.; Pletnev, V.Z. The structure of the pea lectin-D-mannopyranose complex at a 2.1 angstrom resolution. Bioorganicheskaya Khimiya 1998, 24, 313-315.

31. Babino, A.; Tello, D.; Rojas, A.; Bay, S.; Osinaga, E.; Alzari, P.M. The crystal structure of a plant lectin in complex with the Tn antigen. FEBS. Lett. 2003, 536, 106-110. [CrossRef]

32. Imberty, A.; Gohier, A.; Jordan, E.; Goldstein, I.J.; Perez, S. Molecular modeling of native and mutated lima bean lectin: Dissection of lectin/blood group a trisaccharide interactions. Internet J. Chem. 1998, 1, 10.

33. Felger, R.S.; Nabhan, G.P. Agroecosystem diversity: A model from the Sonoran Desert. In Social and Technological Management in the Dry Lands, American Association for the Advancement of Sciences (AAAS) Selected Symposium 10; Gonzalez, N.L., Ed.; Westview Press: Boulder, CO, USA, 1978; pp. 128-149.

34. Sousa, M.; Delgado, A. Mexican leguminosae: Phytogeography, endemism, and origins. In Biological Diversity of Mexico: Origins and Distribution; Oxford University Press: New York, NY, USA, 1993; pp. 459-511.

35. Sousa, S.M.; Medina, R.L.; Andrade, G.; Rico, M.L. Leguminosas. In Biodiversidad de Oaxaca; García, A., Diaz, M., Briones, M., Eds.; Instituto de Biología, Universidad Nacional Autónoma de México, Fondo Oaxaqueño para la Conservación de la Naturaleza, World Wildlife Fund: México, D.F., México, 2004; pp. 249-269.

36. Ortega-Nieblas, M.M. Estudio de Algunas Semillas de Leguminosas del Desierto de Sonora. Factores Antinutricionales y Calidad de sus Proteínas y Aceites. Master's Thesis, Centro de Investigación en Alimentación y Desarrollo, A.C., Sonora, México, 1993.

37. Felipe-Ortega, X. Aislamiento y Caracterización de las Lectinas de Leguminosas Silvestres del Desierto de Sonora: Cercidium praecox (palo de brea) y Caesalpinia caladenia (palo dorado). Bachelor's Thesis, Universidad de Sonora, Sonora, México, August 1996.

38. López-Laredo, A.R. Caracterización de los oligosacáridos de las lectinas de Olneya tesota pf2 y su isoforma más abundante (IF2) y establecer la relación con la función de reconocimiento. Master's Thesis, Centro de Investigación en Alimentación y Desarrollo, A.C., Sonora, México, May 2005.

39. Félix-Favela, F. Isoformas de la lectina PF2, Características Moleculares y Reconocimiento de Leucocitos de Sangre Periférica de Adultos. Master’s Thesis, Centro de Investigación en Alimentación y Desarrollo, A.C., Sonora, México, April 2009.

40. Quirós-Quintero, C.E. Purificación y Caracterización de la Lectina de Prosopis Juliflora y Evaluación del Desarrollo Larval de Zabrotes Subfasciatus en las Semillas. Bachelor's Thesis, Universidad de la Sierra, Sonora, México, February 2010. 
41. Valadez-Vega, C.; Guzmán-Partida, A.M.; Soto-Cordova, F.J.; Álvarez-Manilla, G.; Morales-González, J.A.; Madrigal-Santillán, E.; Villagómez-Ibarra, J.R.; Zúñiga-Pérez, C.; Gutiérrez-Salinas, J.; Becerril-Flores, M.A. Purification, biochemical characterization, and bioactive properties of a lectin purified from the seeds of white tepary bean (Phaseolus acutifolius variety latifolius). Molecules 2011, 16, 2561-2582. [CrossRef] [PubMed]

42. Guzmán-Partida, A.; Félix-Favela, F.; Mata-Haro, V.; Lopez-Laredo, A.; Urbano-Hernández, G.; Robles-Burgueño, M.; Candia-Plata, M.; Vázquez-Moreno, L. Identificación de la interacción de monocitos humanos con las lectinas de Olneya tesota (IF2) y Phaseolus vulgaris (PHA-L) por citometría de flujo. Biotecnia 2013, 15, 3-7. [CrossRef]

43. Miller, J.B.; Noyes, C.; Heinrikson, R.; Kingdon, H.S.; Yachnin, S. Phytohemagglutinin mitogenic proteins. Structural evidence for a family of isomitogenic proteins. J. Exp. Med. 1973, 138, 939-951. [CrossRef] [PubMed]

44. Leavitt, R.D.; Felsted, R.L.; Bachur, N.R. Biological and biochemical properties of Phaseolus vulgaris isolectins. J. Biol. Chem. 1977, 252, 2961-2966. [PubMed]

45. Roberts, D.D.; Etzler, M.E.; Goldstein, I.J. Subunit heterogeneity in the lima bean lectin. J. Biol. Chem. 1982, 257, 9198-9204. [PubMed]

46. Sparvoli, F.; Lanave, C.; Santucci, A.; Bollini, R.; Lioi, L. Lectin and lectin-related proteins in lima bean (Phaseolus lunatus L.) seeds: Biochemical and evolutionary studies. Plant Mol. Biol. 2001, 45, 587-597. [CrossRef] [PubMed]

47. Castillo-Villanueva, A.; Caballero-Ortega, H.; Abdullaev-Jafarova, F.; Garfias, Y.; Jimenez-Martinez, M.D.C.; Bouquelet, S.; Martinez, G.; Mendoza-Hernandez, G.; Zenteno, E. Lectin from Phaseolus acutifolius var. Escumite: Chemical characterization, sugar specificity, and effect on human T-lymphocytes. J. Agric. Food Chem. 2007, 55, 5781-5787. [CrossRef] [PubMed]

48. Vazquez-Moreno, L. Analysis of Olneya tesota lectin peptides with liquid chromatography in two dimensions and tandem mass spectrometry (LC-MS/MS). Manuscript in preparation. 2017.

49. Hoffman, L.M.; Donaldson, D.D. Characterization of 2 Phaseolus-vugaris phytohemagglutinin genes closely linked on the chromosome. EMBO J. 1985, 4, 883-889. [PubMed]

50. Lioi, L.; Sparvoli, F.; Galasso, I.; Lanave, C.; Bollini, R. Lectin-related resistance factors against bruchids evolved through a number of duplication events. Theor. Appl. Genet. 2003, 107, 814-822. [CrossRef] [PubMed]

51. Karnchanatat, A. Antimicrobial activity of lectins from antimicrobial activity of lectins from plants. In Antimicrobial Agents; Bobbarala, V., Ed.; InTech: Rijeka, Croatia, 2012; pp. 145-177.

52. Grandhi, N.J.; Mamidi, A.S.; Surolia, A. Pattern recognition in legume lectins to extrapolate amino acid variability to sugar specificity. In Biochemical Roles of Eukaryotic Cell Surface Macromolecules; Chakrabarti, A., Surolia, A., Eds.; Springer International Publishing: Cham, Switzerland, 2015; pp. 199-215.

53. Cruz, P.H.; Campos, E.P.; Martínez, L.M.; Ortiz, B.; Martínez, G. Las lectinas vegetales como modelo de estudio de las interacciones proteína-carbohidrato. Revista de Educación Bioquímica 2005, 24, 21-27.

54. Sharon, N. Lectin-carbohydrate complexes of plants and animals: An atomic view. Trends Biochem. Sci. 1993, 18, 221-226. [CrossRef]

55. Imberty, A.; Casset, F.; Gegg, C.V.; Etzler, M.E.; Perez, S. Molecular modeling of the Dolichos-biflorus seed lectin and its specific interactions with carbohydrates: $\alpha$-DN-Acetyl-Galactosamine, Forssman disaccharide and blood-group-a trisaccharide. Glycoconj. J. 1994, 11, 400-413. [CrossRef] [PubMed]

56. Young, N.M.; Oomen, R.P. Analysis of sequence variation among legume lectins: A ring of hypervariable residues forms the perimeter of the carbohydrate-binding site. J. Mol. Biol. 1992, 228, 924-934. [CrossRef]

57. Benevides, R.G.; Ganne, G.; Simoes Rda, C.; Schubert, V.; Niemietz, M.; Unverzagt, C.; Chazalet, V.; Breton, C.; Varrot, A.; Cavada, B.S.; et al. A lectin from Platypodium elegans with unusual specificity and affinity for asymmetric complex N-glycans. J. Biol. Chem. 2012, 287, 26352-26364. [CrossRef] [PubMed]

58. Singha, S.; Bose, P.P.; Ganguly, T.; Campana, P.T.; Ghosh, R.; Chatterjee, B.P. Comparison of the nature of interactions of two sialic acid specific lectins Saraca indica and Sambucus nigra with $\mathrm{N}$-acetylneuraminic acid by spectroscopic techniques. J. Lumin. 2015, 160, 119-127. [CrossRef]

59. Chrispeels, M.J.; Raikhel, N.V. Lectins, lectin genes, and their role in plant defense. Plant Cell 1991, 3, 1-9. [CrossRef] [PubMed]

60. Peumans, W.J.; Van Damme, E. Lectins as plant defense proteins. Plant Physiol. 1995, 109, 347. [CrossRef] [PubMed] 
61. Delbaere, L.T.J.; Vandonselaar, M.; Prasad, L.; Quail, J.W.; Wilson, K.S.; Dauter, Z. Structures of the lectin-iv of Griffonia simplicifolia and its complex with the Lewis b human blood-group determinant at 2.0-angstrom resolution. J. Mol. Biol. 1993, 230, 950-965. [CrossRef] [PubMed]

62. Imberty, A.; Gautier, C.; Lescar, J.; Perez, S.; Wyns, L. An unusual carbohydrate binding site revealed by the structures of two Maackia amurensis lectins complexed with sialic acid-containing oligosaccharides. J. Biol. Chem. 2000, 275, 17541-17548. [CrossRef] [PubMed]

63. Kolberg, J.; Michaelsen, T.E.; Sletten, K. Properties of a lectin purified from the seeds of Cicer-arietinum. Hope-Seyler's Z. Physiol. Chem. 1983, 364, 655-664. [CrossRef]

64. Ray, S.; Chatterjee, B.P. Saracin a lectin from saraca-indica seed integument recognizes complex carbohydrates. Phytochem. 1995, 40, 643-649. [CrossRef]

65. Irimura, T.; Tsuji, T.; Tagami, S.; Yamamoto, K.; Osawa, T. Structure of a complex-type sugar chain of human glycophorin A. Biochemistry 1981, 20, 560-566. [CrossRef] [PubMed]

66. Hammarstrom, S.; Hammarstrom, M.L.; Sundblad, G.; Arnarp, J.; Lonngren, J. Mitogenic leukoagglutinin from Phaseolus-vulgaris binds to a pentasaccharide unit in $N$-acetyllactosamine-type glycoprotein glycans. Proc. Natl. Acad. Sci. USA 1982, 79, 1611-1615. [CrossRef] [PubMed]

67. Yamashita, K.; Hitoi, A.; Kobata, A. Structural determinants of Phaseolus-vulgaris erythroagglutinating lectin for oligosaccharides. J. Biol. Chem. 1983, 258, 4753-4755.

68. Kamemura, K.; Furuichi, Y.; Umekawa, H.; Takahashi, T. Purification and characterization of novel lectins from great northern bean, Phaseolus vulgaris L. BBA-Gen. Subj. 1993, 1158, 181-188. [CrossRef]

69. Kaneda, Y.; Whittier, R.F.; Yamanaka, H.; Carredano, E.; Gotoh, M.; Sota, H.; Hasegawa, Y.; Shinohara, Y. The high specificities of Phaseolus vulgaris erythro- and leukoagglutinating lectins for bisecting GlcNac or beta 1-6-linked branch structures, respectively, are attributable to loop B. J. Biol. Chem. 2002, 277, 16928-16935. [CrossRef] [PubMed]

70. Takeya, A.; Hosomi, O.; Nishijima, H.; Ohe, Y.; Sugahara, K.; Sagi, M.; Yamazaki, K.; Hayakawa, H.; Takeshita, H.; Sasaki, C.; et al. Presence of beta-linked GalNac residues on N-glycans of human thyroglobulin. Life Sci. 2007, 80, 538-545. [CrossRef] [PubMed]

71. Rinderle, S.J.; Goldstein, I.J.; Matta, K.L.; Ratcliffe, R.M. Isolation and characterization of amaranthin, a lectin present in the seeds of Amaranthus-caudatus, that recognizes the T-antigen (or cryptic-T)-antigen. J. Biol. Chem. 1989, 264, 16123-16131. [PubMed]

72. Ramos, M.V.; Sampaio, A.H.; Cavada, B.S.; Calvete, J.J.; Grangeiro, T.B.; Debray, H. Characterization of the sugar-binding specificity of the toxic lectins isolated from Abrus pulchellus seeds. Glycoconj. J. 2001, 18, 391-400. [CrossRef] [PubMed]

73. Iskratsch, T.; Braun, A.; Paschinger, K.; Wilson, I.B.H. Specificity analysis of lectins and antibodies using remodeled glycoproteins. Anal. Biochem. 2009, 386, 133-146. [CrossRef] [PubMed]

74. Gomes, F.S.; Procopio, T.F.; Napoleao, T.H.; Coelho, L.C.; Paiva, P.M. Antimicrobial lectin from Schinus terebinthifolius leaf. J. Appl. Microbiol. 2013, 114, 672-679. [CrossRef] [PubMed]

75. Marchaim, D.; Lemanek, L.; Bheemreddy, S.; Kaye, K.S.; Sobel, J.D. Fluconazole-resistant Candida albicans vulvovaginitis. Obstet. Gynecol. 2012, 120, 1407-1414. [CrossRef] [PubMed]

76. Yim, N.-H.; Jung, Y.P.; Cho, W.-K.; Kim, T.; Kim, A.; Im, M.; Ma, J.Y. Screening of aqueous extracts of medicinal herbs for antimicrobial activity against oral bacteria. Integr. Med. Res. 2013, 2, 18-24. [CrossRef]

77. Srivastava, P.; Upreti, D.K.; Dhole, T.N.; Srivastava, A.K.; Nayak, M.T. Antimicrobial property of extracts of Indian lichen against human pathogenic bacteria. Interdiscip. Perspect. Infect. Dis. 2013, 2013, 709348. [CrossRef] [PubMed]

78. Davies, J.; Davies, D. Origins and evolution of antibiotic resistance. Microbiol. Mol. Biol. Rev. 2010, 74, 417-433. [CrossRef] [PubMed]

79. De Brito Marques Ramos, D.; Gomes, F.S.; Napoleão, T.H.; Paiva, P.M.G.; da Silva, M.D.C.; Barroso Coelho, L.C.B. Antimicrobial activity of Cladonia verticillaris lichen preparations on bacteria and fungi of medical importance. Chin. J. Biol. 2014, 2014. [CrossRef]

80. Broekaert, W.F.; Cammue, B.P.A.; DeBolle, M.F.C.; Thevissen, K.; DeSamblanx, G.W.; Osborn, R.W. Antimicrobial peptides from plants. Crit. Rev. Plant Sci. 1997, 16, 297-323. [CrossRef]

81. Lehrer, R.I.; Ganz, T. Antimicrobial peptides in mammalian and insect host defence. Curr. Opin. Immunol. 1999, 11, 23-27. [CrossRef] 
82. Sharon, N.; Lis, H. The structural basis for carbohydrate recognition by lectins. Adv. Exp. Med. Biol. 2001, 491, 1-16. [PubMed]

83. Charungchitrak, S.; Petsom, A.; Sangvanich, P.; Karnchanatat, A. Antifungal and antibacterial activities of lectin from the seeds of Archidendron jiringa Nielsen. Food Chem. 2011, 126, 1025-1032. [CrossRef]

84. Bah, C.S.F.; Fang, E.F.; Ng, T.B. Medicinal applications of plant lectins. In Antitumor Potential and Other Emerging Medicinal Properties of Natural Compounds; Fang, E., Tzi, B., Eds.; Springer International Publishing: Dordrecht, The Netherlands, 2013; pp. 55-74.

85. Oliveira, M.D.L.; Andrade, C.A.S.; Santos-Magalhaes, N.S.; Coelho, L.C.B.B.; Teixeira, J.A.; Carneiro-Da-Cunha, M.G.; Correia, M.T.S. Purification of a lectin from Eugenia uniflora L. seeds and its potential antibacterial activity. Lett. Appl. Microbiol. 2008, 46, 371-376. [CrossRef] [PubMed]

86. Sammour, R.H.; El-Shanshoury, A. Antimicrobial activity of legume seed proteins. Bot. Bull. Acad. Sin. 1992, 31, 185-190.

87. Ayouba, A.; Causse, H.; Vandamme, E.J.M.; Peumans, W.J.; Bourne, Y.; Cambillau, C.; Rouge, P. Interactions of plant-lectins with the components of the bacterial-cell wall peptidoglycan. Biochem. Syst. Ecol. 1994, 22, 153-159. [CrossRef]

88. Santi-Gadelha, T.; Rocha, B.A.M.; Gadelha, C.A.A.; Silva, H.C.; Castellon, R.E.R.; Goncalves, F.J.T.; Toyama, D.O.; Toyama, M.H.; de Souza, A.J.F.; Beriam, L.O.S.; et al. Effects of a lectin-like protein isolated from Acacia Farnesiana seeds on phytopathogenic bacterial strains and root-knot nematode. Pestic. Biochem. Phys. 2012, 103, 15-22. [CrossRef]

89. Islam, B.; Khan, A.U. Lectins: To combat infections. In Protein Purification; Ahmad, R., Ed.; InTech: Rijeka, Croatia, 2012; pp. 167-188.

90. Bourne, Y.; Ayouba, A.; Rouge, P.; Cambillau, C. Interaction of a legume lectin with two components of the bacterial cell wall. A crystallographic study. J. Biol. Chem. 1994, 269, 9429-9435. [PubMed]

91. Qadir, S.; Wani, I.H.; Rafiq, S.; Ganie, S.A.; Masood, A.; Hamid, R. Evaluation of antimicrobial activity of a lectin isolated and purified from Indigofera Heterantha. Adv. Biosci. Biotechnol. 2013, 4, 999. [CrossRef]

92. Yan, Q.J.; Jiang, Z.Q.; Yang, S.Q.; Deng, W.; Han, L.J. A novel homodimeric lectin from Astragalus Mongholicus with antifungal activity. Arch. Biochem. Biophys. 2005, 442, 72-81. [CrossRef] [PubMed]

93. Chen, J.; Liu, B.; Ji, N.; Zhou, J.; Bian, H.J.; Li, C.Y.; Chen, F.; Bao, J.K. A novel sialic acid-specific lectin from Phaseolus coccineus seeds with potent antineoplastic and antifungal activities. Phytomedicine 2009, 16, 352-360. [CrossRef] [PubMed]

94. Silva, H.C.; Pinto, L.D.; Teixeira, E.H.; Nascimento, K.S.; Cavada, B.S.; Silva, A.L.C. Bul: A novel lectin from Bauhinia Ungulata L. Seeds with fungistatic and antiproliferative activities. Process. Biochem. 2014, 49, 203-209. [CrossRef]

95. Barkai-Golan, R.; Mirelman, D.; Sharon, N. Studies on growth inhibition by lectins of penicillia and aspergilli. Arch. Microbiol. 1978, 116, 119-121. [CrossRef] [PubMed]

96. Ye, X.Y.; Ng, T.B.; Tsang, P.W.K.; Wang, J. Isolation of a homodimeric lectin with antifungal and antiviral activities from red kidney bean (Phaseolus vulgaris) seeds. J. Protein Chem. 2001, 20, 367-375. [CrossRef] [PubMed]

97. Leal, A.F.; Lopes, N.E.; Clark, A.T.; de Pontes Filho, N.T.; Beltrao, E.I.; Neves, R.P. Carbohydrate profiling of fungal cell wall surface glycoconjugates of Aspergillus species in brain and lung tissues using lectin histochemistry. Med. Mycol. 2012, 50, 756-759. [CrossRef] [PubMed]

98. Akkouh, O.; Ng, T.B.; Singh, S.S.; Yin, C.M.; Dan, X.L.; Chan, Y.S.; Pan, W.L.; Cheung, R.C.F. Lectins with anti-hiv activity: A review. Molecules 2015, 20, 648-668. [CrossRef] [PubMed]

99. Ingale, A.G.; Hivrale, A.U. Plant as a plenteous reserve of lectin. Plant Signal Behav. 2013, 8, e26595. [CrossRef] [PubMed]

100. Mukhopadhyay, B.; Martins, M.B.; Karamanska, R.; Russell, D.A.; Field, R.A. Bacterial detection using carbohydrate-functionalised cds quantum dots: A model study exploiting E. coli recognition of mannosides. Tetrahedron Lett. 2009, 50, 886-889. [CrossRef]

101. Charan, R.D.; Munro, M.H.G.; O’Keefe, B.R.; Sowder, R.C.; McKee, T.C.; Currens, M.J.; Pannell, L.K.; Boyd, M.R. Isolation and characterization of Myrianthus holstii lectin, a potent HIV-1 inhibitory protein from the plant Myrianthus Holstii. J. Nat. Prod. 2000, 63, 1170-1174. [CrossRef] [PubMed] 
102. Matsui, T.; Kobayashi, S.; Yoshida, O.; Ishii, S.; Abe, Y.; Yamamoto, N. Effects of succinylated concanavalin a on infectivity and syncytial formation of human-immunodeficiency-virus. Med. Microbiol. Immun. 1990, 179, 225-235. [CrossRef]

103. Hansen, J.E.; Nielsen, C.M.; Nielsen, C.; Heegaard, P.; Mathiesen, L.R.; Nielsen, J.O. Correlation between carbohydrate structures on the envelope glycoprotein gp120 of HIV-1 and HIV-2 and syncytium inhibition with lectins. Aids 1989, 3, 635-641. [CrossRef] [PubMed]

104. Dan, X.L.; Liu, W.L.; Ng, T.B. Development and applications of lectins as biological tools in biomedical research. Med. Res. Rev. 2016, 36, 221-247. [CrossRef] [PubMed]

105. Wong, J.H.; Ng, T.B.; Cheung, R.C.; Ye, X.J.; Wang, H.X.; Lam, S.K.; Lin, P.; Chan, Y.S.; Fang, E.F.; Ngai, P.H.; et al. Proteins with antifungal properties and other medicinal applications from plants and mushrooms. Appl. Microbiol. Biotechnol. 2010, 87, 1221-1235. [CrossRef] [PubMed]

106. Adams, D.J. Fungal cell wall chitinases and glucanases. Microbiology 2004, 150, 2029-2035. [CrossRef] [PubMed]

107. Lis, H.; Sharon, N. Lectins in higher plants. In The Biochemistry of Plants; Marcus, A., Ed.; Academic Press Inc.: New York, NY, USA, 1981; Volume 6, pp. 371-447.

108. Ciopraga, J.; Gozia, O.; Tudor, R.; Brezuica, L.; Doyle, R.J. Fusarium sp growth inhibition by wheat germ agglutinin. BBA-Gen. Subj. 1999, 1428, 424-432. [CrossRef]

109. Van Parijs, J.; Broekaert, W.F.; Goldstein, I.J.; Peumans, W.J. Hevein: An antifungal protein from rubber-tree (Hevea brasiliensis) latex. Planta 1991, 183, 258-264. [CrossRef] [PubMed]

110. Boleti, A.P.D.; Freire, M.D.M.; Coelho, M.B.; da Silva, W.; Baldasso, P.A.; Gomes, V.M.; Marangoni, S.; Novello, J.C.; Macedo, M.L.R. Insecticidal and antifungal activity of a protein from Pouteria torta seeds with lectin-like properties. J. Agric. Food Chem. 2007, 55, 2653-2658. [CrossRef] [PubMed]

111. Rao, V.S.R.; Lam, K.; Qasba, P.K. Three dimensional structure of the soybean agglutinin-Gal/GalNac complexes by homology modeling. J. Biomol. Struct. Dyn. 1998, 15, 853-860. [CrossRef] [PubMed]

112. Vigerust, D.J.; Shepherd, V.L. Virus glycosylation: Role in virulence and immune interactions. Trends Microbiol. 2007, 15, 211-218. [CrossRef] [PubMed]

113. Ziolkowska, N.E.; Wlodawer, A. Structural studies of algal lectins with anti-hiv activity. Acta Biochim. Pol. 2006, 53, 617-626. [PubMed]

114. Keyaerts, E.; Vijgen, L.; Pannecouque, C.; Van Damme, E.; Peumans, W.; Egberink, H.; Balzarini, J.; Van Ranst, M. Plant lectins are potent inhibitors of coronaviruses by interfering with two targets in the viral replication cycle. Antivir. Res. 2007, 75, 179-187. [CrossRef] [PubMed]

115. Lusvarghi, S.; Bewley, C.A. Griffithsin: An antiviral lectin with outstanding therapeutic potential. Viruses 2016, 8, 296. [CrossRef] [PubMed]

116. Fei Fang, E.; Ho Wong, J.; Lin, P.; Bun Ng, T. Biochemical and functional properties of a lectin purified from korean large black soybeans a cultivar of glycine max. Protein Pept. Lett. 2010, 17, 690-698. [CrossRef]

117. Macedo, M.L.R.; das Graças Machado Freire, M.; da Silva, M.B.R.; Coelho, L.C.B.B. Insecticidal action of Bauhinia monandra leaf lectin (bmoll) against Anagasta kuehniella (lepidoptera: Pyralidae), Zabrotes subfasciatus and Callosobruchus maculatus (coleoptera: Bruchidae). Comp. Biochem. Physiol. A Mol. Integr. Physiol. 2007, 146, 486-498. [CrossRef] [PubMed]

118. Melander, M.; Åhman, I.; Kamnert, I.; Strömdahl, A.-C. Pea lectin expressed transgenically in oilseed rape reduces growth rate of pollen beetle larvae. Transgenic Res. 2003, 12, 555-567. [CrossRef] [PubMed]

119. Michiels, K.; Van Damme, E.J.; Smagghe, G. Plant-insect interactions: What can we learn from plant lectins? Arch. Insect Biochem. Physiol. 2010, 73, 193-212. [CrossRef] [PubMed]

120. Dandagi, P.; Mastiholimath, V.; Patil, M.; Gupta, M. Biodegradable microparticulate system of captopril. Int. J. Pharm. 2006, 307, 83-88. [CrossRef] [PubMed]

121. Walski, T.; Van Damme, E.J.; Smagghe, G. Penetration through the peritrophic matrix is a key to lectin toxicity against Tribolium castaneum. J. Insect Physiol. 2014, 70, 94-101. [CrossRef] [PubMed]

122. Roy, A.; Gupta, S.; Hess, D.; Das, K.P.; Das, S. Binding of insecticidal lectin Colocasia esculenta tuber agglutinin (cea) to midgut receptors of Bemisia tabaci and Lipaphis erysimi provides clues to its insecticidal potential. Proteomics 2014, 14, 1646-1659. [CrossRef] [PubMed]

123. Francis, F.; Marty-Detraves, C.; Poincloux, R.; Baricault, L.; Fournier, D.; Paquereau, L. Fungal lectin, xcl, is internalized via clathrin-dependent endocytosis and facilitates uptake of other molecules. Eur. J. Cell Biol. 2003, 82, 515-522. [CrossRef] [PubMed] 
124. Caccia, S.; Van Damme, E.J.; De Vos, W.H.; Smagghe, G. Mechanism of entomotoxicity of the plant lectin from Hippeastrum hybrid (amaryllis) in spodoptera Littoralis larvae. J. Insect Physiol. 2012, 58, 1177-1183. [CrossRef] [PubMed]

125. Zhu-Salzman, K.; Salzman, R.A. Functional mechanics of the plant defensive Griffonia simplicifolia lectin II: Resistance to proteolysis is independent of glycoconjugate binding in the insect gut. J. Econ. Entomol. 2001, 94, 1280-1284. [CrossRef] [PubMed]

126. Fitches, E.; Wiles, D.; Douglas, A.E.; Hinchliffe, G.; Audsley, N.; Gatehouse, J.A. The insecticidal activity of recombinant garlic lectins towards aphids. Insect Biochem. Mol. Biol. 2008, 38, 905-915. [CrossRef] [PubMed]

127. Du, J.; Foissac, X.; Carss, A.; Gatehouse, A.M.; Gatehouse, J.A. Ferritin acts as the most abundant binding protein for snowdrop lectin in the midgut of rice brown planthoppers (Nilaparvata lugens). Insect Biochem. Mol. Biol. 2000, 30, 297-305. [CrossRef]

128. Sadeghi, A.; Smagghe, G.; Proost, P.; Van Damme, E.J. Ferritin acts as a target site for the snowdrop lectin (gna) in the midgut of the cotton leafworm spodoptera littoralis. Insect Sci. 2008, 15, 513-519. [CrossRef]

129. Napoleão, T.H.; Pontual, E.V.; de Albuquerque Lima, T.; de Lima Santos, N.D.; Sá, R.A.; Coelho, L.C.B.B.; do Amaral Ferraz Navarro, D.M.; Paiva, P.M.G. Effect of myracrodruon urundeuva leaf lectin on survival and digestive enzymes of Aedes aegypti larvae. Parasitol. Res. 2012, 110, 609-616. [CrossRef] [PubMed]

130. Sprawka, I.; Goławska, S.; Goławski, A.; Chrzanowski, G.; Czerniewicz, P.; Sytykiewicz, H. Entomotoxic action of jackbean lectin (con a) in bird cherry-oat aphid through the effect on insect enzymes. J. Plant Interact. 2014, 9, 425-433. [CrossRef]

131. Bala, A.; Roy, A.; Behura, N.; Hess, D.; Das, S. Insight to the mode of action of allium sativum leaf agglutinin (asal) expressing in $\mathrm{t} 3$ rice lines on brown planthopper. Am. J. Plant Sci. 2013, 4, 400-407. [CrossRef]

132. Lagarda-Diaz, I.; Guzman-Partida, A.M.; Huerta-Ocampo, J.A.; Winzerling, J.; Vazquez-Moreno, L. Identification of membrane proteins of the midgut of Zabrotes subfasciatus larvae associated with the insecticidal mechanism of PF2 lectin. J. Asia-Pacif. Entomol. 2016, 19, 677-682. [CrossRef]

133. Lagarda-Diaz, I.; Robles-Burgeño, M.R.; Guzman-Partida, A.M.; Geiser, D.; Winzerling, J.; Vazquez-Moreno, L. Binding of PF2 lectin from Olneya tesota to gut proteins of Zabrotes subfasciatus larvae associated with the insecticidal mechanism. J. Agric. Food Chem. 2012, 60, 2398-2402. [CrossRef] [PubMed]

134. Upadhyay, S.K.; Singh, P.K. Receptors of garlic (Allium sativum) lectins and their role in insecticidal action. Protein J. 2012, 31, 439-446. [CrossRef] [PubMed]

135. Shen, L.; Luo, Z.; Wu, J.; Qiu, L.; Luo, M.; Ke, Q.; Dong, X. Enhanced expression of $\alpha 2$, 3-linked sialic acids promotes gastric cancer cell metastasis and correlates with poor prognosis. Int. J. Oncol. 2017, 50, 1201-1210. [PubMed]

136. Litynska, A.; Przybyuulo, M.; Pochec, E.; Hoja-uuLukowicz, D.; Ciouulczyk, D.; Laidler, P.; Gil, D. Comparison of the lectin-binding pattern in different human melanoma cell lines. Melanoma Res. 2001, 11, 205-212. [CrossRef] [PubMed]

137. Korourian, S.; Siegel, E.; Kieber-Emmons, T.; Monzavi-Karbassi, B. Expression analysis of carbohydrate antigens in ductal carcinoma in situ of the breast by lectin histochemistry. BMC Cancer 2008, 8, 136. [CrossRef] [PubMed]

138. Blomme, B.; Van Steenkiste, C.; Callewaert, N.; Van Vlierberghe, H. Alteration of protein glycosylation in liver diseases. J. Hepatol. 2009, 50, 592-603. [CrossRef] [PubMed]

139. Fu, L.L.; Zhou, C.C.; Yao, S.; Yu, J.Y.; Liu, B.; Bao, J.K. Plant lectins: Targeting programmed cell death pathways as antitumor agents. Int. J. Biochem. Cell Biol. 2011, 43, 1442-1449. [CrossRef] [PubMed]

140. Stauder, H.; Kreuser, E.-D. Mistletoe extracts standardised in terms of mistletoe lectins (ml i) in oncology: Current state of clinical research. Oncol. Res. Treat. 2002, 25, 374-380. [CrossRef]

141. Jiang, Q.L.; Zhang, S.; Tian, M.; Zhang, S.Y.; Xie, T.; Chen, D.Y.; Chen, Y.J.; He, J.; Liu, J.; Ouyang, L. Plant lectins, from ancient sugar-binding proteins to emerging anti-cancer drugs in apoptosis and autophagy. Cell Prolif. 2015, 48, 17-28. [CrossRef] [PubMed]

142. Hajela, K.; Kojima, M.; Ambrus, G.; Wong, K.H.; Moffatt, B.E.; Ferluga, J.; Hajela, S.; Gál, P.; Sim, R.B. The biological functions of MBL-associated serine proteases (MASPs). Immunobiology 2002, 205, 467-475. [CrossRef] [PubMed] 
143. Panda, P.K.; Mukhopadhyay, S.; Behera, B.; Bhol, C.S.; Dey, S.; Das, D.N.; Sinha, N.; Bissoyi, A.; Pramanik, K.; Maiti, T.K. Antitumor effect of soybean lectin mediated through reactive oxygen species-dependent pathway. Life Sci. 2014, 111, 27-35. [CrossRef] [PubMed]

144. Kim, M.; Rao, M.; Tweardy, D.; Prakash, M.; Galili, U.; Gorelik, E. Lectin-induced apoptosis of tumour cells. Glycobiology 1993, 3, 447-453. [CrossRef] [PubMed]

145. Chang, C.P.; Lei, H.Y. Autophagy induction in $\mathrm{t}$ cell-independent acute hepatitis induced by concanavalin a in scid/nod mice. Int. J. Immunopathol. Pharmacol. 2008, 21, 817-826. [CrossRef] [PubMed]

(C) 2017 by the authors. Licensee MDPI, Basel, Switzerland. This article is an open access article distributed under the terms and conditions of the Creative Commons Attribution (CC BY) license (http://creativecommons.org/licenses/by/4.0/). 